$=$ 原 著 $=$

\title{
東京都内における非発症調理従事者の ノロウイルス排泄期間
}

\author{
林 志 直 ${ }^{\dagger}$ 秋場 哲 哉・森 功 次 \\ 永野美由紀・甲斐明 美 \\ (東京都健康安全研究センター) \\ (受付：平成 23 年 8 月 21 日) \\ (受理：平成 24 年 3 月 13 日)
}

\section{Duration of Norovirus RNA Excretion in Asymptomatic Food-Handlers in Tokyo}

\author{
Yukinao Hayashi $^{\dagger}$, Tetsuya AkIBA, Kohji Mori, \\ Miyuki Nagano and Akemi KaI \\ (Tokyo Metropolitan Institute of Public Health, 3-24-1 Hyakunin-cho, \\ Shinjuku-ku, Tokyo $169-0073 ;{ }^{\dagger}$ Coresponding author)
}

\begin{abstract}
Norovirus (NoV) is one of the most important causative agent of food-borne gastroenteritis outbreaks. Studies of NoV outbreaks associated with food-handlers who were infected with NoV have been frequently reported. However, precise reports on the duration of NoV shedding from food-handlers are not found. In this report, we examined 94 stool specimens from 28 foodhandlers in 10 food-borne outbreaks for the duration of NoV RNA excretion during the period from April 2009 to March 2010. The median duration of viral shedding was 21.9 days after causative foods were prepared. 17 food-handlers out of $28(61 \%)$ excreted NoV RNA in the stool until 18 days after causative foods were prepared. However, five food-handlers out of 28 (18\%) excreted NoV RNA more than one month. When more than ten days have passed after causative foods were prepared, the quantity of $\mathrm{NoV}$ excreted in feces from all 5 food-handlers decreased in the range of $1.7 \times 10^{4}$ to $9.6 \times 10^{6} / \mathrm{g}$, and became negative after the excretion continued in the same range for three to five weeks. We should monitor carefully food-handlars who excreted NoV RNA to prevent the spread of food poisoning associated with NoV.
\end{abstract}

Key words: Norovirus, food-borne gastroenteritis, real-time PCR, food-handler, viral shedding

\section{緒言}

急性胃腸炎症状を呈するウイルス性食中毒は冬季を中 心に発生し，主な病原ウイルスは)ロウイルス（Norovirus, 以下 $\mathrm{NoV}$ と略), サポウイルス(Sapovirus), ロ夕 ウイルス(Rotavirus), アストロウイルス(Astrovirus), アデノウイルス(Adenovirus)などである ${ }^{8)}$.なかでも $\mathrm{NoV}$ はウイルス性食中毒の最も重要な病因ウイルスで

\section{連絡先}

函169-0073 東京都新宿区百人町 3-24-1
あり, 乳幼児から高齢者まで幅広い年齢層に感染し, 哣 吐・下㾥・腹痛・発熱などの症状を引き起こす，東京都 において 2001 年から 2010 年までの 10 年間に発生した食 中毒の病因物質別の事例数 ${ }^{10,11)}$ (平成 22 年東京都食中毒 発生状況 (確定值) : http://www.fukushihoken.metro. tokyo.jp/shokuhin/tyuudoku/h22_kakutei.html) では, 2008年を除いて毎年 NoVに起因する事例が最も多かっ た. $\mathrm{NoV}$ 食中毒は, 主として NoVが蓄積したカキなど の二枚貝を生食または加熱不十分で喫食, あるいは NoVに感染した調理従事者により污染された食品を喫 
食することにより発生すると考えられている2． 特に近 年は, 調理従事者の食品污染が原因と推定される食中毒 事例が非常に多い3.7).

$\mathrm{NoV}$ が糞便から検出された調理従事者は，食中毒防 止対策を進めるうえで陰性確認が必要であるが, 非発症 者における NoV排泄期間などに関する報告は少ない. 本論文では 2009 年 4 月から 2010 年 3 月の 1 年間に東京都 内で発生した食中毒事例のウイルス検索において, NoV 陽性となった調理従事者について経時的に瞥便を検査 し，陰性確認を行った結果， $\mathrm{NoV}$ の長期排泄者の存在 が明らかとなったので報告する。

\section{材料と方法}

\section{1. 検査材料}

2009 年 4 月から 2010 年 3 月の間に発生した NoVによ る食中毒 10 事例に関連した非発症調理従事者 28 名から の糞便 94 件を対象にした.

\section{2. 検查方法}

\section{1) 検査材料の前処理}

検査材料（糞便）はPBS $(-)$ ( $\mathrm{pH} 7.4$ : 日水製薬）によ り $10 \%$ 乳剤を調整し， $3,000 \mathrm{rpm}, 10$ 分遠心分離(HITACHI himac CF8DL)を行った。 その上清を分取し，核 酸抽出材料とした.

\section{2) 核酸抽出}

核酸の抽出は, 核酸抽出材料 $140 \mu l$ から厚生労働省通 知法 ${ }^{5)}$ に示されたQIAamp Viral RNA Mini Kit (QIAGEN)を用いて行った。キットの添付書に従って操作を 行い, 核酸抽出液 $60 \mu l$ を得た。

\section{3) cDNA 合成}

逆転写反応は, $5 \times$ First Strand Buffer (Invitrogen) $6 \mu l, 2.5 \mathrm{mM}$ dNTPs (TaKaRa) $1.5 \mu l, 1 \mu \mathrm{g} / \mu l$ Random hexamer (Amersham Biosciences) $0.75 \mu l, 100 \mathrm{mM} \mathrm{Di-}$ thiothreitol (Invitrogen) $1.5 \mu l, 40 \mathrm{U} / \mu l$ RNase inhibitor （ナカライテスク） $1 \mu l, 200$ U/ $\mu l$ Super Script II RN$\mathrm{aseH}^{-}$逆転写酵素 (Invitrogen) $1.5 \mu l$, 打よび蒸留 水 $5.75 \mu l$ と核酸抽出液 $12 \mu l$ を混合し， $42^{\circ} \mathrm{C}, 60$ 分の反 応により行い, cDNAを作製した

\section{4）ノロウイルス遺伝子の検出}

$\mathrm{NoV}$ 遺伝子の検出は，厚生労働省通知法 ${ }^{5)}$ に基づいた リアルタイムPCR法により実施した。すなわち，cDNA $5 \mu l$ と $2 \times$ TaqMan Universal PCR Master Mix (Applied Biosystems) $12.5 \mu l$, プライマー各 $0.2 \mu l$, プローブ 0.3 $\mu l$ ，扔上び蒸留水 $6.8 \mu l$ を用いて, ABI PRISM $7900^{\mathrm{TM}}$ (Applied Biosystems)により行った. プライマーおよび プローブは， NoV 遺伝子群I（以下 $\mathrm{GI}$ と略）検出用には COG1F/COG1R (100 pmol/ $\mu l)$, RING1-TP (a) $(30 \mathrm{pmol} /$ $\mu l), \mathrm{NoV}$ 遺伝子群 II (以下 GII と略) 検出用にはCOG2F/ COG2R $(100 \mathrm{pmol} / \mu l)$, RING2-TP $(10 \mathrm{pmol} / \mu l)$ を用い, PCR 反応は $50^{\circ} \mathrm{C} 2$ 分, $95^{\circ} \mathrm{C} 10$ 分の後, $94^{\circ} \mathrm{C} 15$ 秒, $56^{\circ} \mathrm{C}$ 1分を 45 サイクルにより行った。国立感染症研究所から
分与された GI およびGIIの標的領域を組み込んだプラス

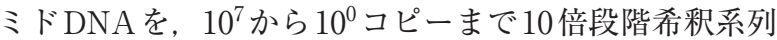
を作成して試料と同時に検查し, 得られた検量線から糞 便試料 $1 \mathrm{~g}$ 当たりの $\mathrm{NoV}$ 遺伝子コピー数を算出した。リ アルタイムPCR 測定時に1ウェル（1試料）当たり10コ ピー以下を陰性と判定した。

\section{5）ノロウイルスの遺伝子解析}

前述の方法により NoV 陽性と判定した材料について, 遺伝子解析を行った。検出されたNoVGIIの解析には COG2F/G2SKRの領域を対象としたRT-PCR法 ${ }^{4)}$ を行い, PCR 産物を Montage-PCR (Millipore)を用いて精製し, BigDye Terminator v1.1 Cycle Sequencing Kit (Applied Biosystems)によるシークエンス反応を行った，反応産 物をCentri-Sep ${ }^{\mathrm{TM}}$ Spin Columns (Applied Biosystems) を用いて精製し，ABI PRISM ${ }^{\mathrm{TM}}$ Genetic Analyzer 3100 (Applied Biosystems)により塩基配列を決定した，得ら れた塩基配列はClustal Xによりアライメントを作成し， boot strap $=1,000$ として近隣結合法による遺伝子系統樹 解析 ${ }^{4)}$ から遺伝子型を判定した.

\section{結果}

\section{1. 調査対象とした食中毒事例の概要}

調査期間中にNoVに起因する食中毒が 67 事例発生 し, 38 事例において調理従事者から $\mathrm{NoV} か ゙$ 検出され, このうち調查が可能であった 10 事例の非発症調理従事 者 28 名について NoV 陰性確認試験を実施した。調查対 象とした事例は，飲食店での発生例が 4 事例，披露宴・ 法事等の会食料理提供施設が 4 事例，仕出弁当やケー夕 リングなどの食品販売を行う施設が 2 事例であった．事 例から検出された $\mathrm{NoV} の$ 遺伝子型は $\mathrm{GII} / 2$ が 1 事例, $\mathrm{GII} / 4$ が 7 事例, GII/7が 1 事例, GII/2 と GII/13の同時 検出例が1事例であった (Table 1).

\section{2. 調理従事者の NoV 陰性確認試験}

調查対象とした 10 事例の調理従事者 28 名からの NoV 陰性確認試験成績を示した(Table 2)。原因食品が提供 された4日後から8日後までに食中毒事件の原因解明の ために NoV 検査が行われ，調理従事者の糞便から $10^{4} \sim$ $10^{9}$ コピー $/ \mathrm{g}$ 糞便の $\mathrm{NoV}$ 遺伝子が検出された。なお，こ の検査法の検出限界は $2.1 \times 10^{4}$ コピー $/ \mathrm{g}$ 翼便であった.

陰性確認試験を目的とした検查材料の採取は 1 週間の 間隔を基本とし, 最短 11 日後から最長 53 日後で調查対 象とした調理従事者全員の NoV 陰性が確認された。な お, 調理従事者は発症していないため, 発症後の日数で はなく，原因食品を提供した日を基準とした経過日数で 示した．28名中14名 (50\%) では，1回の陰性確認試験 により NoVを排出していないことが確認された。

NoV 陰性確認までに要した日数の度数分布を Fig. 1 に 示した．18日目までに陰性となった調理従事者は28名 中 17 名 $(61 \%)$ であったが，陰性確認に 4 週間以上を要 した調理従事者も5名（18\%）認められた。 
Table 1. Norovirus-associated outbreaks studied

\begin{tabular}{|c|c|c|c|c|c|c|}
\hline \multirow{2}{*}{ No. } & \multirow{2}{*}{ Date } & \multicolumn{2}{|c|}{ No. of } & \multirow{2}{*}{$\begin{array}{l}\text { Type of } \\
\text { settings }\end{array}$} & \multirow{2}{*}{$\begin{array}{c}\text { No. of food- } \\
\text { handlers tested }\end{array}$} & \multirow{2}{*}{$\begin{array}{l}\text { Genotype of } \\
\text { NV associated }\end{array}$} \\
\hline & & Persons at risk & Patients & & & \\
\hline 1 & 2009.5 & 182 & 57 & Funeral service & 5 & $\mathrm{GII} / 4$ \\
\hline 2 & 12 & 7 & 6 & Funeral service & 6 & $\mathrm{GII} / 2, \mathrm{GII} / 13$ \\
\hline 3 & 12 & Unknown & 17 & Restaurant & 1 & $\mathrm{GII} / 4$ \\
\hline 4 & 12 & 11 & 8 & Funeral service & 1 & $\mathrm{GII} / 4$ \\
\hline 5 & 2010. 1 & 45 & 29 & Fast food & 2 & $\mathrm{GII} / 4$ \\
\hline 6 & 1 & 22 & 12 & Fast food & 1 & $\mathrm{GII} / 2$ \\
\hline 7 & 1 & 36 & 32 & Restaurant & 6 & $\mathrm{GII} / 7$ \\
\hline 8 & 1 & 21 & 6 & Restaurant & 1 & $\mathrm{GII} / 4$ \\
\hline 9 & 1 & 62 & 25 & Wedding party & 2 & $\mathrm{GII} / 4$ \\
\hline 10 & 1 & 105 & 11 & Restaurant & 3 & $\mathrm{GII} / 4$ \\
\hline
\end{tabular}

Table 2. Detection of Norovirus RNA in stools of food-handlers

\begin{tabular}{|c|c|c|c|c|c|c|c|c|}
\hline \multirow{2}{*}{$\begin{array}{c}\text { No. of } \\
\text { outbreak- } \\
\text { food-handler }\end{array}$} & \multirow{2}{*}{$\begin{array}{l}\text { Genotype } \\
\text { of NV } \\
\text { detected }\end{array}$} & \multirow{2}{*}{$\begin{array}{c}\begin{array}{c}\text { No. of } \\
\text { copies }\end{array} \\
\begin{array}{c}\text { Original } \\
\text { examination }\end{array}\end{array}$} & \multicolumn{6}{|c|}{ NV negative confirmation test: No. of copies } \\
\hline & & & 1 st & 2nd & $3 r d$ & 4 th & 5 th & 10th \\
\hline $1-1$ & $\mathrm{GII} / 4$ & $3.3 \times 10^{6}(5)^{*}$ & ND (11) & & & & & \\
\hline $1-2$ & & $8.1 \times 10^{7}(5)$ & ND (11) & & & & & \\
\hline $1-3$ & & $1.0 \times 10^{9}(5)$ & $1.4 \times 10^{7}(11)$ & $5.9 \times 10^{5}(18)$ & $\mathrm{ND}(26)$ & & & \\
\hline $1-4$ & & $3.2 \times 10^{8}(5)$ & $4.2 \times 10^{5}(11)$ & $8.0 \times 10^{4}(18)$ & $2.1 \times 10^{5}(26)$ & $6.4 \times 10^{4}(33)$ & ND (47) & \\
\hline $1-5$ & & $7.9 \times 10^{8}(7)$ & $2.1 \times 10^{4}(11)$ & $1.4 \times 10^{5}(18)$ & $2.1 \times 10^{4}(26)$ & ND (33) & & \\
\hline $2-1$ & $\mathrm{GII} / 2$ & $8.2 \times 10^{6}(4)$ & $9.7 \times 10^{4}(10)$ & $3.4 \times 10^{5}(13)$ & ND (17) & & & \\
\hline $2-2$ & & $1.1 \times 10^{6}(5)$ & $7.0 \times 10^{4}(10)$ & $4.6 \times 10^{4}(13)$ & ND (17) & & & \\
\hline $2-3$ & & $3.8 \times 10^{7}(5)$ & $6.9 \times 10^{4}(10)$ & $2.8 \times 10^{4}(13)$ & $4.0 \times 10^{4}(16)$ & $7.5 \times 10^{4}(17)$ & $\mathrm{ND}(21)$ & \\
\hline $2-4$ & GII/13 & $4.3 \times 10^{8}(5)$ & $6.4 \times 10^{4}(10)$ & $4.5 \times 10^{4}(13)$ & ND (17) & & & \\
\hline $2-5$ & & $3.5 \times 10^{8}(5)$ & ND (16) & & & & & \\
\hline $2-6$ & & $9.3 \times 10^{7}(7)$ & $\mathrm{ND}(21)$ & & & & & \\
\hline $3-1$ & $\mathrm{GII} / 4$ & $1.0 \times 10^{5}(8)$ & ND (17) & & & & & \\
\hline $4-1$ & $\mathrm{GII} / 4$ & $2.1 \times 10^{4}(8)$ & ND (17) & & & & & \\
\hline $5-1$ & $\mathrm{GII} / 4$ & $1.2 \times 10^{7}(4)$ & ND (14) & & & & & \\
\hline $5-2$ & & $6.6 \times 10^{7}(4)$ & ND (14) & & & & & \\
\hline $6-1$ & $\mathrm{GII} / 2$ & $1.1 \times 10^{7}(6)$ & $4.2 \times 10^{5}(12)$ & ND (26) & & & & \\
\hline $7-1$ & $\mathrm{GII} / 7$ & $3.9 \times 10^{4}(4)$ & $3.9 \times 10^{4}(13)$ & ND (24) & & & & \\
\hline $7-2$ & & $1.8 \times 10^{5}(6)$ & ND (16) & & & & & \\
\hline $7-3$ & & $7.8 \times 10^{5}(6)$ & $3.4 \times 10^{5}(16)$ & $1.1 \times 10^{6}(27)$ & ND (48) & & & \\
\hline $7-4$ & & $4.6 \times 10^{4}(8)$ & ND (18) & & & & & \\
\hline $7-5$ & & $1.5 \times 10^{5}(8)$ & ND (16) & & & & & \\
\hline $7-6$ & & $2.6 \times 10^{5}(8)$ & ND (13) & & & & & \\
\hline $8-1$ & $\mathrm{GII} / 4$ & $9.0 \times 10^{4}(4)$ & ND (16) & & & & & \\
\hline $9-1$ & $\mathrm{GII} / 4$ & $1.1 \times 10^{7}(4)$ & $9.6 \times 10^{5}(12)$ & $1.6 \times 10^{5}(17)$ & $1.1 \times 10^{4}(24)$ & ND (34) & & \\
\hline $9-2$ & & $1.6 \times 10^{5}(5)$ & ND (12) & & & & & \\
\hline $10-1$ & $\mathrm{GII} / 4$ & $6.0 \times 10^{4}(6)$ & $6.0 \times 10^{4}(11)$ & ND (17) & & & & \\
\hline $10-2$ & & $2.0 \times 10^{7}(7)$ & $1.8 \times 10^{5}(12)$ & $2.8 \times 10^{4}(18)$ & ND (21) & & & \\
\hline $10-3^{* *}$ & & $2.0 \times 10^{8}(6)$ & $5.6 \times 10^{4}(11)$ & $3.5 \times 10^{4}(17)$ & $3.7 \times 10^{4}(20)$ & $2.4 \times 10^{4}(25)$ & $8.4 \times 10^{4}(28)$ & ND (53) \\
\hline
\end{tabular}

* Numbers in the parenthesis are the days after causative foods were prepared, ND: not detected

** 6 th : $2.8 \times 10^{4}(33), 7$ th : $4.5 \times 10^{4}(39), 8$ th: $2.5 \times 10^{4}(42), 9$ th: $3.0 \times 10^{4}(47)$

\section{3. 陰性確認試験における NoV 遺伝子コピー数の推} 移

$\mathrm{NoV}$ 陰性が確認されるまでに要した日数によって3週 間以内 17 名 (Fig. 2A), 3 週間から4週間以内6名(Fig. 2B), 4 週間以上 5 名 (Fig. 3)に分け, 非発症調理従事者
の糞便中に排出される NoV 遺伝子コピー数の推移を示 した. 3 週間以内に NoV 陰性確認された調理従事者 17 名のうち, 15 名の粪便に排出される NoV 遺伝子コピー 数は日数の経過とともに減少した(Fig. 2A). しかし, 陰性確認に 3 週間から 4 週間以内を要した群では, 6例 


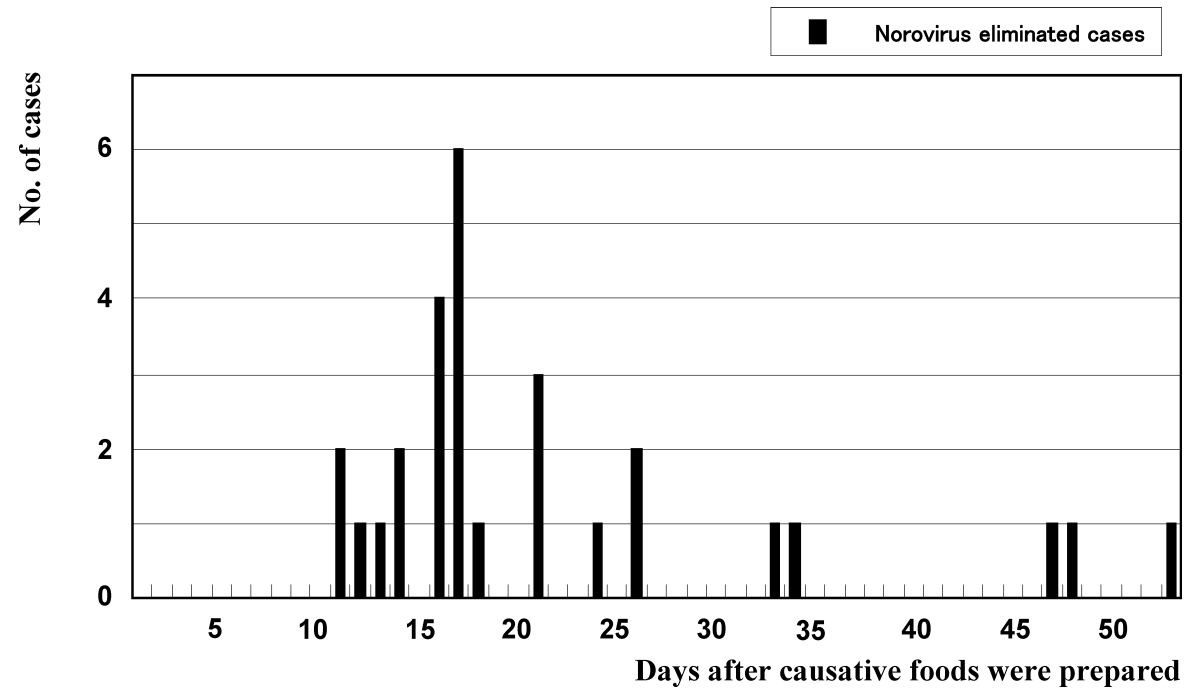

Fig. 1. Distribution of the days Norovirus eliminated in asymptomatic food-handlers

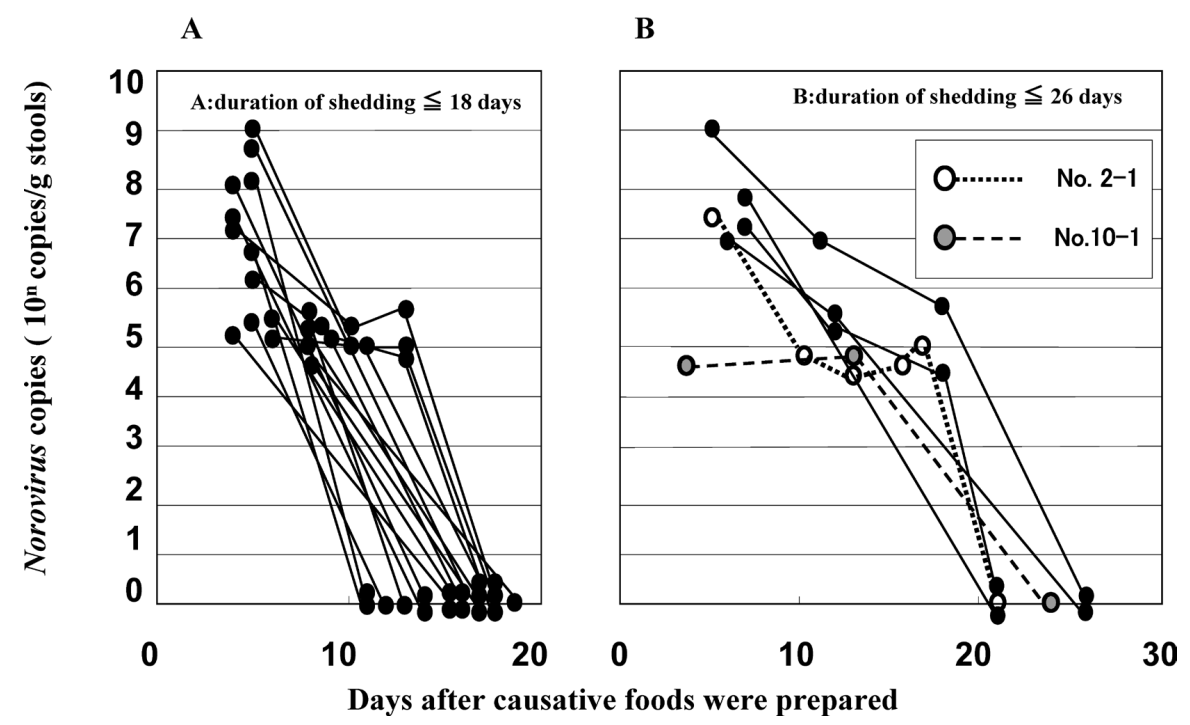

Fig. 2. Duration of Norovirus RNA shedding in food-handlers

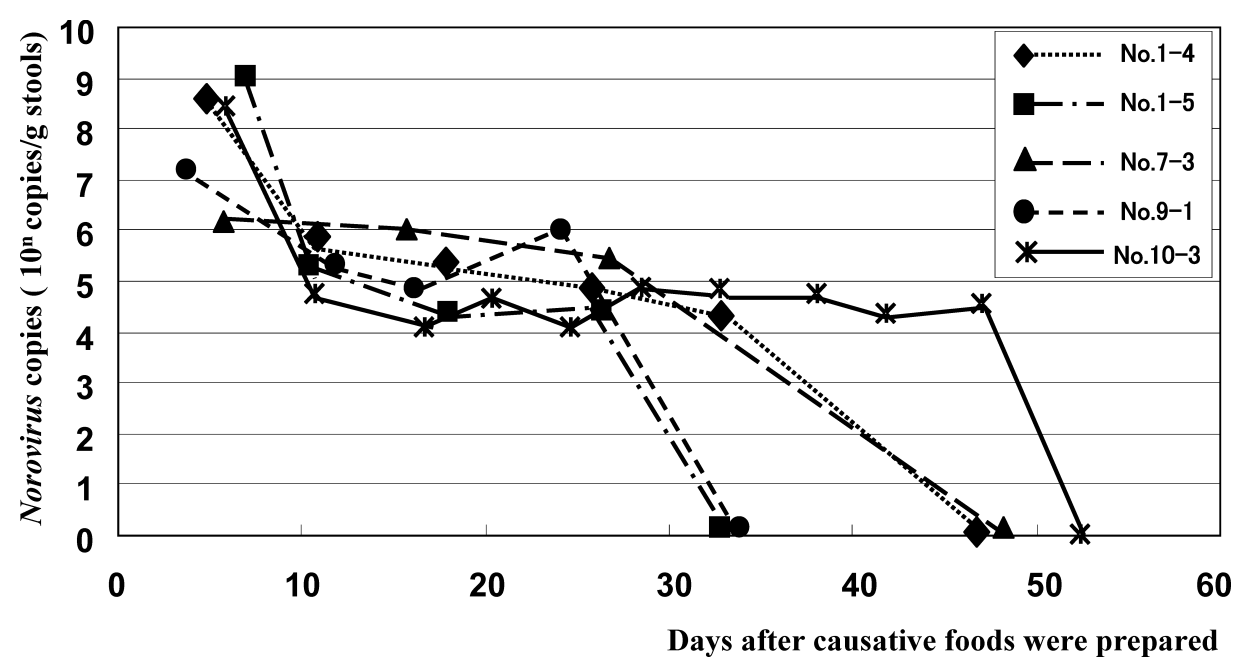

Fig. 3. Kinetics of Norovirus RNA shedding longer than 30 days 
中2例（従業員 2-1 と 10-1）で $\mathrm{NoV}$ 遺伝子コピー数が $10^{4}$ $\sim 10^{5} / \mathrm{g}$ 粪便の状態が 1 週間程度認められた後に陰性化 した(Fig. 2B). 陰性確認に4週間以上を要した群では, 最初の $\mathrm{NoV}$ 検索において $7.8 \times 10^{6}$ から $7.9 \times 10^{8}$ コピー $/ \mathrm{g}$ 糞便の $\mathrm{NoV}$ 遺伝子が検出された後, 原因食品が調理さ れて 10 日以上経過すると翼便中の $\mathrm{NoV}$ 遺伝子コピー数 は $1.7 \times 10^{4} \sim 9.6 \times 10^{5} / \mathrm{g}$ 翼便まで減少し, NoV コピー数 が $10^{4} \sim 10^{6} / \mathrm{g}$ 粪便の範囲で 3 週間から 5 週間継続した後 に陰性化した(Fig. 3). NoV 排泄が4週間以上続いた調 理従事者から検出された遺伝子型は 4 名から GII/4, 1名 から GII/7であった.

\section{考察}

2009 年 4 月から 2010 年 3 月までに発生した $\mathrm{NoV}$ 食中 毒 67 事例のうち 10 事例の非発症者の調理従事者 28 名か らの糞便 94 件について, NoV 陰性確認試験を実施した。 調査対象とした調理従事者の健康状態は良好であった。 しかし, 調查対象はすべて食中毒事例であり, 推定原因 食の契食日は特定されている。このため, 今回は推定原 因食品が提供された日を基準とした経過日数で表した.

$\mathrm{NoV}$ 陽性となった調理従事者が NoV 陰性と確認され るまでに要した日数は, 3 週間以内 17 名, 3 週間から 4 週間以内 6 名, 4 週間以上 5 名, 平均 21.9 日であった. 陰性確認試験は毎日実施されたものではないため, 要し た日数は過大評価されている面もあるが，長期にわたり $\mathrm{NoV}$ が排泄されていることは明らかである，杉枝らの 報告9) では非発症の調理従事者5名について資便から経 時的に $\mathrm{NoV}$ 検策を行い, このうち 3 名では初回検查から 15 日後にも $10^{4} \sim 10^{7}$ コピー $/ \mathrm{g}$ 糞便の $\mathrm{NoV}$ 遺伝子を検出 している，森らの報告6)では, 調理従事者から翼便に排

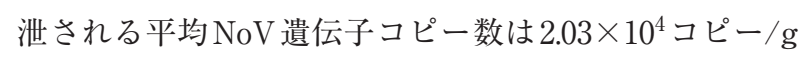
糞便であり, 13 名中 2 名では初回検查時から 22 日後と 32 日後に NoVを検出している。 また, 厚生労働省「ノ ロウイルスに関する Q \& A」 (www.mhlm.go.jp/topics) syokuchu/kanren/yobou/0424-1.html, 平成 23 年 5 月 29 日改定）では, NoV陽性となった調理従事者は通常 1 週 間，長いときは 1 カ月以上 $\mathrm{NoV}$ を排泄することが記載 されている. 今回の調査に扔いても排出ウイルス量はこ れまでの発症者の成績 6 , 9 とほぼ同様であり, 非発症者 28名中 5 名 (18\%)において陰性確認まで1カ月以上の 長期間を要した者も認められた。

CDC 2011 年にノロウイルス対策ガイドライン ${ }^{1) を ~}$ 改定し, 食品取扱者, 保育・介護・医療関係者は症状回 復後 48〜 72 時間の勤務制限を提示している. しかし, 今回の調查に扔いて, NoV排泄が1カ月以上続いた調理 従事者の嚬便に含まれる $\mathrm{NoV}$ 遺伝子コピー数は $10^{4} \sim$ $10^{6}$ コピー $/ \mathrm{g}$ 糞便を維持し, $\mathrm{NoV}$ 感染拡大の原因となり うることが判明した．NoV食中毒の再発を防ぐために は検出感度の高い核酸増幅法による陰性確認検查を実施 し，陰性確認まで調理従事者の従事制限を継続すること
が必要と考える.

近年 $\mathrm{NoV}$ 食中毒から検出される $\mathrm{NoV}$ の遺伝子型にも 変化が認められている。 ノロウイルス食中毒が多発した 2006/2007 流行期には GII/4がほとんどを占めていたが, 2008/2009 流行期は GII/4の占める割合は 50\% 以下に低 下している ${ }^{12)}$. 今回の調査においても, NoVの排出が 1 力月以上継続する調理従事者から検出された NoVの遺 伝子型に $\mathrm{GII} / 7$ が認められ，さまざまな $\mathrm{NoV}$ 遺伝子型に 起因する食中毒が予想される. 今後, NoVの長期排泄 に関しては, その要因についてウイルス側·宿主側両面 から検討する必要性が示された。

\section{要 約}

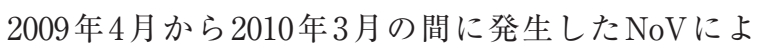
る食中毒 10 事例に関連した調理従事者 28 名から, 経日 的に共便94件を採取し，NoV 陰性確認試験を実施した。 推定原因食品提供後に, NoV 陰性が確認されるまでに 要した日数は平均21.9日であった。調理従事者 28 名中 17名 (61\%) は3週間以内に㓌性となったが，5名 (18\%) では陰性確認に 4 週間以上を要した. $\mathrm{NoV}$ 排泄が 4 週間 以上続いた調理従事者に扔いては, 10 日以上経過する と翼便中の $\mathrm{NoV}$ 遺伝子コピー数が $1.7 \times 10^{4} \sim 9.6 \times 10^{5} / \mathrm{g}$ 賴便まで減少し，この状態が3週間から5週間継続した 後に陰性化した. $\mathrm{NoV}$ 食中毒の再発防止のために調理 に直接従事する者の陰性確認試験の重要性が示された。

\section{文献}

1) CDC: Updated norovirus outbreak management and disease prevention guidelines. MMWR Recommendations and Reports, 60 (2011).

2）林 志直：ノロウイルス食中毒と感染性胃腸炎。食衛 誌, 51, 279-284 (2010).

3）林 志直, 森 功次, 野口やよい, 秋場哲哉, 吉田靖子, 山田澄夫：胃腸炎集団発生から検出されたノロウイルス の遺伝子解析. 東京健安研七年報, 57, 83-86 (2006).

4) Kageyama, T., Shinohara, M., Uchida, K., Fukushi, S., Hoshino, B.F., Kojima, S., Takai, R., Oka, T., Takeda, N. and Katayama, K.: Coexistence of multiple genotypes, including newly identified genotypes, in outbreaks of gastroenteritis due to Norovirus in Japan. J. Clin. Microbiol., 42, 2988-2995(2004).

5）厚生労働省医薬食品局食品安全部監視安全課長：ノロウ イルスの検查法について。平成19年5月14日, 食安監 発第0514004号 (2007).

6）森 功次, 林 志直, 佐々木由紀子, 野口や上い, 甲斐 明美, 諸角 聖: 発症者および非発症者䨢便中に排出さ れる Norovirus 遺伝子量の比較. 感染症誌, 79, 521-526 (2005).

7）永野美由紀, 林 志直, 秋場哲哉, 森 功次, 田中達 也，保坂三継，甲斐明美：都内に打ける胃腸炎集団発生 例のウイルス検索 (平成 19-20年度)。東京健安研七年 報, 60, 55-59 (2009).

8）西尾 治：ウイルス感染症. 食品由来感染症と食品微生 物. 仲西寿男, 丸山務監修, p. 510-514, 中央法規出版, 
東京 (2009).

9）杉枝正明，新川奈緒美，大瀬戸光明，徳竹由美，山口 卓, 秋山美穂, 西尾 治: Norovirus 感染により排泄さ れるウイルス量について. 臨床とウイルス, 32, 189-194 (2004).

10）東京都福祉保健局健康安全室：平成 17 年東京都の食中
毒概要 (2007).

11）東京都福祉保健局健康安全部：平成 21 年東京都の食中毒 概要 (2011).

12）東京都健康安全研究センター：ノロウイルス対策緊急夕 スクフォース最終報告 (2010). 